\title{
The Management of Student's Pocket Money
}

\author{
Rendika Vhalery, Hasdi Aimon, and Yulhendri
}

UNIVERSITAS NEGERI PADANG

\begin{abstract}
The purpose of this study is to clarify the factors that influence the management of students' pocket money directly and indirectly in Air Tawar Padang City. A sample of 344 students consisting of 130 students and 214 high school students was obtained by completing the questionnaire. The results show that the family environment, peers, gender and self-control have positive and significant effect on the management of students in Padang City.
\end{abstract}

Index Terms- pocket money; family environment; peers; gender; and self-control

\section{INTRODUCTION}

tudent's behavior of using pocket money is getting worse. If it continues to be ignored, it is feared that it will have a negative impact on the welfare or success of future students [1], [2]. Several studies have been conducted to socialize the management of pocket money [3]-[6]. For example, Furnham \& Milner; Kirkcaldy, Furnham, and T. Martin in [3], [4] socialize pocket money in the community. It is considered a social phenomenon [7]. On the other hand, we consider this phenomenon as an opportunity to develop science. Therefore, this needs to be considered by the community, educational institutions, and government.

The study of pocket money management in Indonesia can be categorized as minimal and limited among students. Students in Padang City know that they use "pocket money" but do not know how to manage their pocket money. The survey shows that $60.7 \%$ of students do not manage their pocket money well. Though managing pocket money is a form of responsibility that teaches the meaning of money [8]. Most pocket money is allocated for food, drinks, clothing, and other things [9]. The remaining pocket money is used for school / campus purposes and for savings [10], [11]. We do not find students who set aside pocket money for illness or unexpected events.

Olsson in [12] asserts that every student activity starts from the social environment. Family environment dominates most of the activities at home. The establishment of financial capability in the family environment through interaction between parents and children [3], [10], [13]-[15]. On the other hand, most of the time students are spent outside with peers [16]. This activity creates a bond that affects financial ability through the provision of support and information [12], [17]. Therefore, the social environment greatly improves students' pocket management abilities [12], [17].

Khare in [18] suggests that gender affects the management of the student's pocket money. Male students use money to play games, hang out, and buy cigarettes [16]. Female students use money to buy food, drink and clothing [9]. However, [14] did not see any difference. Therefore, this study to further ensure this relationship.

According to some studies, the low skill of managing pocket money relates to student self-control [19], [20]. High selfcontrol affects proper, controlled, and prudent management of money management [8]. In contrast, uncontrolled behavior indicates that learners have low self-control [16]. Because of that, self control mediates the relationship between the environment of families, friends, and gender towards the management of pocket money. The conseptual frame could be explained as follows:

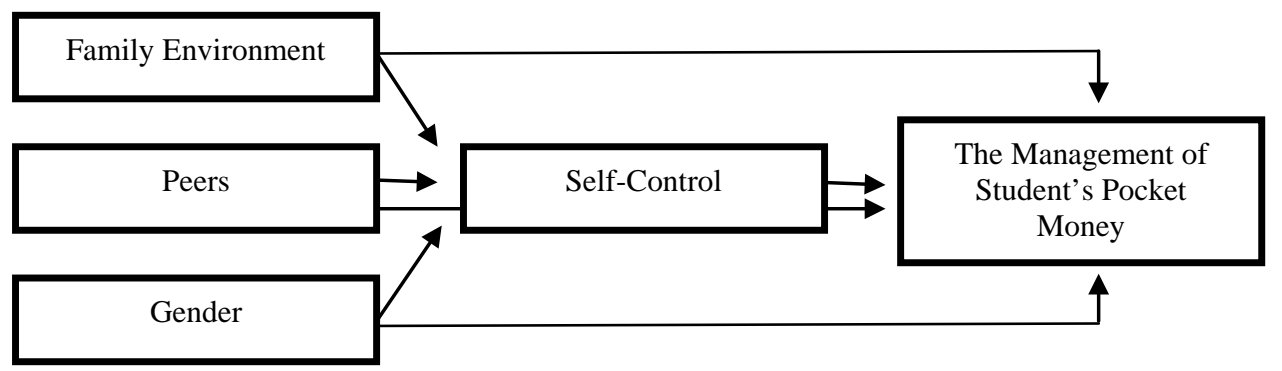

Figure 1. Conseptual frame

This study has several objectives. The first objective is to briefly discuss the management of student pocket money based on the studies that have been done. In addition to information to develop the ability to maintain financial stability. The second objective is to clarify the factors that affect the management of student pocket money directly and indirectly based on the proposed conceptual framework (figure 1).

The next discussion of this study is structured as follows. Section 2 examines the latest literature on pocket money management. Section 3 discusses the methods used to analyze data. Section 4 presents the results of research briefly. Section 5 is the conclusions. 


\section{LITERATURE REVIEW}

Pocket money is the income that the student receives from a parent or guardian [7]. In practice, children are given the freedom to do whatever they want [21], such as spending money, managing money, saving, or for social activities [13]. This freedom is expected to shape the financial ability of their experience [5].

The management of pocket money is a study of financial management [22], which can be determined from the following activities. First, the planning before using the pocket money [13]; to avoid financial crisis problems now and later [21]. Second, keeping incoming and outgoing money [23]; is the first step to get used to a positive routine. Third, arranging expenditures is intended to increase confidence, responsibility, and avoid consumptive behavior [18]. Fourth, set aside some money to save [24]. As venture capital and investment achieve economic prosperity [25].

\section{METHOD}

The design of quantitative research is using the type of associative research.The population is focused on Air Tawar area consisting of Universitas Negeri Padang, SMA Development of Laboratory of UNP, and SMA Pertiwi 1 which is amounted to 2,447 students. By using proportionate stratified random sampling technique in the Sample of 344 students consisting of 130 (37.8\%) students and 214 high school students (62.2\%) of which 137 (39.8\%) are men, and 207 ( $60.2 \%)$ are women. the age range is between $15-22$ years, with an average age of 17 years old.

The questionnaire includes four sections referring to 17 indicators (see appendix). Questionnaires were submitted to respondents for answers based on Likert scale (1) - (5) and nominal scale (1) for female students and (0) for male students. The validity and reliability test were performed for the questionnaire. It was continued with the test of normality, homogeneity, path analysis and hypothesis testing with 5\% error rate using SPSS 24.0 program.

\section{RESUlT}

The purpose of this study is to clarify the indirect influence and direct effect of pocket money management variables using lane analysis. The path analysis is divided into 2 structures. The first structure (Table 1) describes the influence of family environment variables, peers, and gender against self-control variables. The second structure (Table 4) describes the influence of the family environment, peers, gender, and self-control over the management of student pocket money.

Table 1. Results of structure 1

\begin{tabular}{|c|c|c|c|c|c|}
\hline \multirow{2}{*}{ Model } & $\begin{array}{l}\text { Unstan } \\
\text { Coeffic }\end{array}$ & $\begin{array}{l}\text { ized } \\
\text { S }\end{array}$ & $\begin{array}{l}\text { Standardized } \\
\text { Coefficients }\end{array}$ & \multirow[b]{2}{*}{$\mathrm{t}$} & \multirow{2}{*}{ Sig. } \\
\hline & B & $\begin{array}{l}\text { Std. } \\
\text { Error }\end{array}$ & Beta & & \\
\hline (Constant) & 28,719 & 6,071 & & 4,730 & 0,000 \\
\hline Family Environmnet & 0,538 & 0,086 & 0,321 & 6,229 & 0,000 \\
\hline Peers & 0,223 & 0,062 & 0,189 & 3,605 & 0,000 \\
\hline Gender & 0,362 & 1,032 & 0,018 & 0,351 & 0,726 \\
\hline
\end{tabular}

Dependent Variable: Self-control

Based on the result of structure 1 (Table 1) family and peer environment variables have significant effect while the gender variable has no effect and not significant with sig value $0,726>\alpha 0,05$. The Triming Test takes out the gender variables of the model. The results can be seen in Table 3 below:

Table 2. Results structure 1 (without gender variables)

\begin{tabular}{|c|c|c|c|c|c|}
\hline \multirow{2}{*}{ Model } & \multicolumn{2}{|c|}{$\begin{array}{l}\text { Unstandardized } \\
\text { Coefficients }\end{array}$} & $\begin{array}{l}\text { Standardized } \\
\text { Coefficients }\end{array}$ & \multirow[b]{2}{*}{$\mathrm{t}$} & \multirow{2}{*}{ Sig. } \\
\hline & $\mathrm{B}$ & $\begin{array}{l}\text { Std. } \\
\text { Error }\end{array}$ & Beta & & \\
\hline (Constant) & 29,120 & 5,995 & & 4,890 & 0,000 \\
\hline Family Environment & 0,538 & 0,086 & 0,321 & 6,237 & 0,000 \\
\hline Peers & 0,219 & 0,061 & 0,185 & 3,609 & 0,000 \\
\hline
\end{tabular}

Dependent Variable: Self-control

The final result of structure 1 (Table 2) shows that the coefficient of path variable of the family environment is $\beta=0.321$ and the sig value. $0.00<\alpha 0.05$ means having a positive and significant influence. Peer variable coefficient coefficient of $\beta=0,185$ and sig value. $0.00<\alpha 0.05$ means having a positive and significant influence. The effect of other variables can be calculated through the value of $\mathrm{R}^{2}$ (Table 3 ) as follows: 
Table 3. Large influence of independent variables of structure 1

\begin{tabular}{lllll}
\hline Model & $\mathrm{R}$ & R Square & Adjusted R Square & Std. Error of the Estimate \\
\hline 1 &, 414 &, 171 &, 164 & 9,184 \\
\hline \multicolumn{5}{c}{$=\sqrt{1-R^{2}}=\sqrt{1-0,171}=0,911$}
\end{tabular}

The first path analysis structure between the family environment, peers, and other variables of self-control can be seen in Figure 2 below:

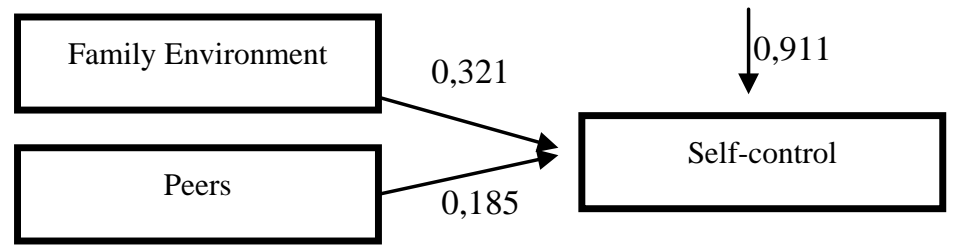

Figure 2. Structure of path analysis 1

Structure 2 describes the direct influence of family environment variables, peers, gender, and self-control on the management of student pocket money in Air Tawar Kota Padang. The output results (Table 4) describes the path coefficients. Output Output (Table 5) describes the contribution of other independent variables.

Table 4. Results of structure 2

\begin{tabular}{|c|c|c|c|c|c|}
\hline \multirow{2}{*}{ Model } & \multicolumn{2}{|c|}{$\begin{array}{l}\text { Unstandardized } \\
\text { Coefficients }\end{array}$} & $\begin{array}{l}\text { Standardized } \\
\text { Coefficients }\end{array}$ & \multirow{2}{*}{$\mathrm{t}$} & \multirow{2}{*}{ Sig. } \\
\hline & $\mathrm{B}$ & $\begin{array}{l}\text { Std. } \\
\text { Error }\end{array}$ & Beta & & \\
\hline (Constant) & 6,096 & 5,874 & & 1,038 & 0,300 \\
\hline Family Environment & 0,271 & 0,085 & 0,167 & 3,170 & 0,002 \\
\hline Peers & 0,139 & 0,059 & 0,122 & 2,350 & 0,019 \\
\hline Gender & 2,170 & 0,967 & 0,110 & 2,244 & 0,025 \\
\hline Self-control & 0,287 & 0,051 & 0,297 & 5,647 & 0,000 \\
\hline
\end{tabular}

Dependent Variable: The management of student’s pocket money

The result of structure 2 (Table 5) shows that the coefficient of path of family environment variable equal to $\beta=0,167$ or $16,7 \%$ with sig value. $0.002<\alpha 0.05$, meaning the family environment has a direct and positive direct effect on the management of pocket money. Peer variable coefficient equals to $\beta=0,122$ or $12,2 \%$ with sig value. $0,019<\alpha 0,05$, meaning that peers have a direct positive and significant effect on the management of student pocket money. The gender variable coefficient of $\beta=0.110$ or $11 \%$ with the sig value. $0.025<\alpha 0.05$, which means that gender has a direct and positive direct effect on the management of students' pocket money. The coefficient of self-control variable path is $\beta=0,297$ or $29,7 \%$ with sig value. $0,000<\alpha 0.05$, means that self-control has a direct and positive direct effect on the management of student pocket money.

Tabel 5. Large influence of independent variables of structure 2

\begin{tabular}{lllll}
\hline Model & $\mathrm{R}$ & $\mathrm{R}$ Square & Adjusted R Square & Std. Error of the Estimate \\
\hline 1 &, 471 &, 221 &, 212 & 8,606 \\
\hline
\end{tabular}

The effect of other variables can be calculated through the value of $\mathrm{R}^{2}$ (Table 5) as follows:

$P y \varepsilon_{2} \quad=\sqrt{1-R^{2}}=\sqrt{1-0,221}=0,883$

The second path analysis structure between family environment, peers, gender, self-control and other variables on student pocket management can be seen in Figure 3 as follows: 


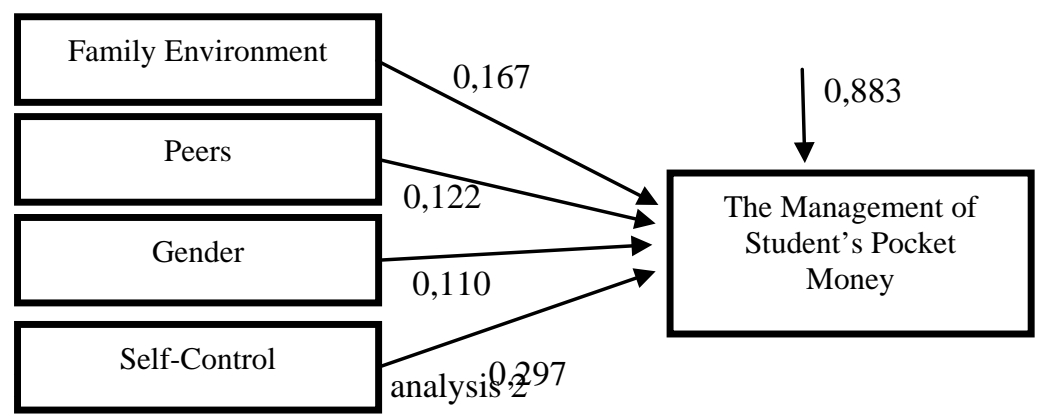

The result of the first and second structures combined into one part will form a new pathway structure. It could be seen in Figure 4 as follows:

Figure 4 The end structure pathway

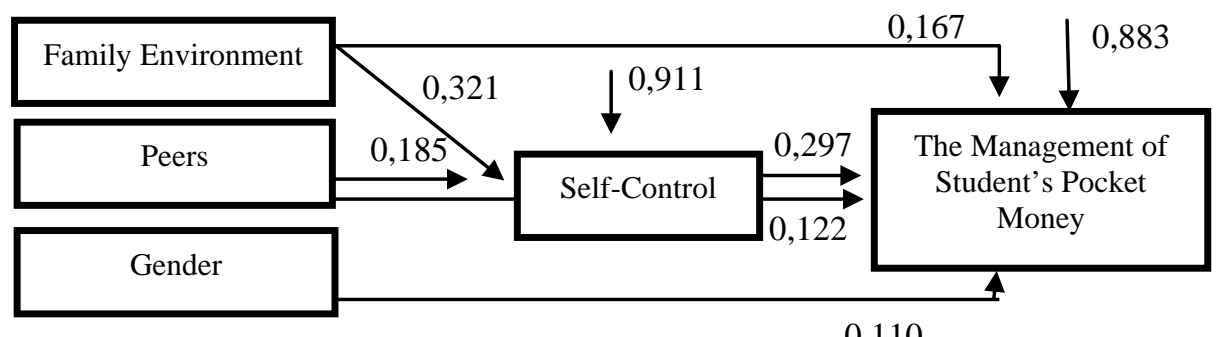

\section{CONClUSION}

Managing pocket money is one way of avoiding consumptive behavior and minimizing negative impacts. Planning and execution are the key to managing pocket money. Mature planning will facilitate the process of activities to be implemented. Good implementation refers to prepared planning.

Pathway analysis clarifies the indirect influence and direct influence on the management of student pocket money. First, the family environment and peers have an indirect effect on the management of pocket money through self-control. This suggests that the family environment and peers form a student self-control that is useful for managing pocket money. This forming process is created through the exchange of information, the sharing of experiences, and the sharing of knowledge on how to manage the pocket money. Second, the family environment, peers, gender and self-control directly influence the management of pocket money.

\section{APPENDIX}

Table 1a. Questionnaire Instrument

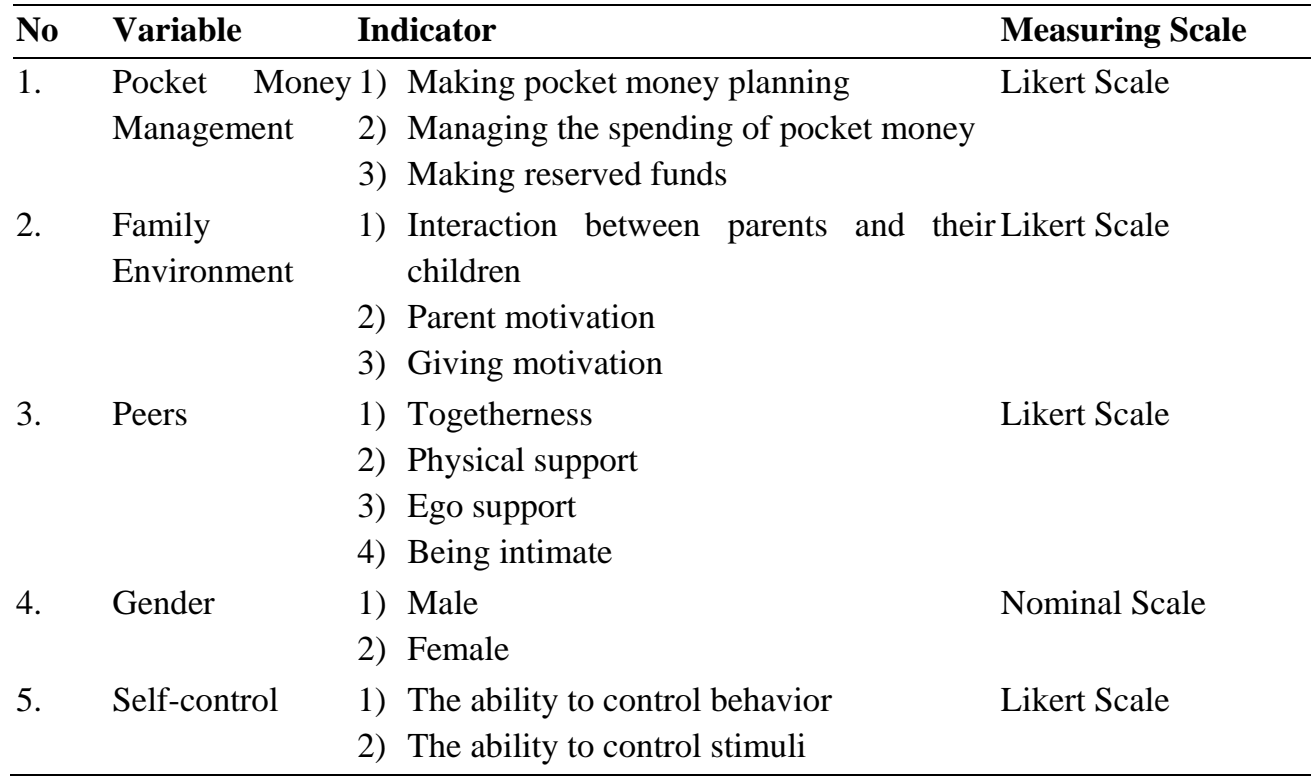



3) The ability to anticipate events
4) The ability to interpret events
5) The ability to make decisions

\section{REFERENCES}

[1] B. Van Groezen and L. Meijdam, “Growing old and staying young: population policy in an ageing closed economy,” J. Popul. Econ., vol. 21, no. 3, pp. 573-588, Jul. 2008.

[2] G. B. Dahl and L. J. Lochner, "The Impact of Family Income on Child Achievement : Evidence from the Earned Income Tax Credit,” 2010.

[3] A. Furnham and R. Milner, "Parent's Beliefs and Behaviours about the Economic Socialisation, through Allowances/Pocket Money, of Their Children,” Psychology, vol. 8, no. 8, pp. 1216-1228, 2017.

[4] B. Kirkcaldy, A. Furnham, and T. Martin, "Parental attitudes towards pocket money, trait competitiveness and occupational stress,” J. Manag. Psychol., vol. 18, no. 4, pp. 305-323, 2003.

[5] A. J. Scott and A. Lewis, "The economic awareness, knowledge, and pocket money practices of a sample of UK adolescents: A study of economic socialisation and economic psychology,” Citizenship, Soc. Econ. Educ., vol. 4, no. 1, p. 34, 2000.

[6] E. Fornero, M. Rossi, and D. Sansone, “ “Four Bright Coins Shining at Me ’ Financial Education In Childhood , Financial Confidence in Adulthood,” no. July, 2016.

[7] A. A. Shah, Z. F. Syed, and S. H. B. J. B. M. Aslam, “Pocket Money as a proxy for Family Income,” Int. J. Soc. Sci. Educ., vol. 2, no. 4, pp. 688-693, 2012.

[8] J. Bamforth and G. M. Geursen, “Categorising the money management behaviour of young consumers,” Young Consum., vol. 45, no. 2, pp. 227-241, 2017.

[9] L. Higgins, A. Silva, and I. Parada, "Impact of Child-Directed TV Food Advertising Regulations on Pocket Money Allowances,” Agric. Appl., 2016.

[10] J. Bonke, "Do Danish children and young people receive pocket money?," Rockwool Foundat. Res. Unit, no. 57, 2013.

[11] P. Webley and E. K. Nyhus, "Economic socialization, saving and assets in European young adults," Economics of Education Review, vol. 33, Elsevier Ltd, pp. 19-30, 2012.

[12] E. Olsson, “The economic side of social relations: household poverty, adolescents' own resources and peer relations," Eur. Sociol. Rev., vol. 23, no. 4, pp. 471-485, 2007.

[13] A. Bucciol and M. Veronesi, “Teaching children to save: What is the best strategy for lifetime savings?,” J. Econ. Psychol., vol. 45, pp. 1-17, 2014.

[14] C. Barnet-Verzat and W. François-Charles, "Pocket money and child effort at school,” Econ. Bull., vol. 9, no. 13, 2008.

[15] S. Kolodziej, K. Lato, and M. Szymańska, "The Role of Parental Influences on the Economic Socialization of Children,” vol. 58, 2014.

[16] A. Pandayu, B. Murti, and Pawito, "Effect of Personal Factors , Family Support , Pocket Money , and Peer Group , on Smoking Behavior in Adolescents in Surakarta , Central Java,” J. Heal. Promot. Behav., vol. 2, no. 2, pp. 98-111, 2017.

[17] J. Bamforth, C. Jebarajakirthy, and G. M. Geursen, “Undergraduates’ responses to factors affecting their money management behaviour: some new insights from a qualitative study,” Young Consum., 2017.

[18] A. Khare, "Money attitudes , credit card and compulsive buying behaviour : a study on Indian consumers Arpita Khare," vol. 5, pp. 49-71, 2016.

[19] B. De Clercq, “Do our children know anything about money? An exploratory study,” Meditari Account. Res., vol. 17, no. 1, p. 1-1 3, 2009.

[20] J. Banks, “Cognitive function, financial literacy and financial outcomes at older ages: Introduction,” Econ. J., vol. 120, no. 548, pp. 357-362, 2010.

[21] T. W. Bradford, “Earmarking Money and Consumption,” Consum. Cult. Theory, vol. 3, no. 3, pp. 167-183, 2014.

[22] W. Su and M. Deng, "Survey and Thought of Financial Management and Education in High School Students in Nanjing," Creat. Educ., vol. 3, no. 2, pp. 228-231, 2012.

[23] D. M. Figart, V. King, and F. Drive, “Economics and personal finance education are complements , not substitutes,” vol. 3, no. 4, pp. 354-360, 2012.

[24] A. Otto, “Saving in childhood and adolescence: Insights from developmental psychology,” Economics of Education Review, vol. 33, Elsevier Ltd, pp. 8-18, 2012.

[25] J. J. H. Flavio Cunha and S. M. Schennach, "Estimating the technology of cognitive and noncognitive skill formation," Econometrica, vol. 78, no. 3, pp. 883-931, 2010. 


\section{AUTHORS}

Rendika Vhalery, S.Pd - is a student of the economical study master program in the Economic Faculty of Universitas Negeri Padang (UNP). rendikavhalery31@gmail.com

Prof. Dr. Hasdi Aimon, M.Si - is the lecturer in Universitas Negeri Padang (UNP) and is the head of the environmental study program for the doctoral (Dr) program in the Economic Faculty of UNP. His focus of study is economic building in Indonesia especially in Padang. s3dkpl@gmail.com

Dr. Yulhendri, M.Si - is the lecturer in Universitas Negeri Padang (UNP) and is the third vice dean in the Economic Faculty of UNP. His focus of study is economic building, coperation, and study strategies. Yulhendriunp@gmail.com 